\title{
Soviet Jewry In The Decisive Decade, 1971-80
}

\section{Robert Owen Freedman}

Holdings: Soviet Jewry in the decisive decade, 1971-80 York. Soviet Jewry in the Decisive Decade, 1971-80. Front Cover - Robert Owen Freedman. Duke University Press, 1984 - Social Science - 167 pages. Soviet Jewry in the Decisive Decade, 1971-80 - Google Books Result Soviet Jewry in the decisive decade, 1971-80 edited by Robert O. Buy Soviet Jewry in the Decisive Decade, 1971-80 Duke Press. Type: Book Authors: Freedman, Robert Date: 1984 Publisher: Duke University Press Pub place: Durham, N.C. ISBN-10: 0822305445 ISBN-13 Advertising PDF If you Buy It Now, you'll only be purchasing this item. If you'd like to get the additional items you've selected to qualify for this offer, close this window and add Soviet Jewry in the Decisive Decade, 1971-80 by Robert O. Available in the National Library of Australia collection. Format: Book xvi, 167 p.: ill. $25 \mathrm{~cm}$. Soviet Jewry in the Decisive Decade, 1971-80 - Robert Owen. Read Soviet Jewry in the Decisive Decade, 1971-80 Duke Press Policy Series book reviews \& author details and more at Amazon.in. Free delivery on qualified Decade, 1971-80 Duke Press policy studies PDF is available at our online library. With our complete resources, you could find Soviet Jewry in the Decisive Soviet Jewry in the decisive decade, 1971-80 University of. This book, which contains nine papers by various authors, concerns the migration of approximately a quarter million Jews from the USSR during the 1970s. SOVIET JEWRY IN THE DECISIVE DECADE, 1971-80 by Robert. Much of this volume is devoted to what happens to Soviet Jews after they emigrate to Israel or America, but the investigations also cover several aspects of. Criss-Crossing Identities: The Russian Jewish Diaspora and the. Soviet Jewry in the Decisive Decade, 1971-80 by Robert Owen Freedman, Robert Owen Freedman, 9780822305446 , available at Book Depository with free. This book is shelved in the Russian History section of our retail store and may require extra shipping time Crisp clean unread unmarked hardcover with light. Soviet Jewry in the Decisive Decade, 1971-80: Robert Owen. PDF - Are you searching for Soviet Jewry in the Decisive Decade, 1971-80 Duke Press policy studies Hardcover Books? Now, you will be happy that at this. Get this from a library! Soviet Jewry in the decisive decade, 1971-80. Robert Owen Freedman Soviet Jewry in the Decisive Decade, 1971-80 Duke. - Amazon.com Amazon.in - Buy Soviet Jewry in the Decisive Decade, 1971-80 book online at best prices in India on Amazon.in. Read Soviet Jewry in the Decisive Decade, Soviet Jewry in the decisive decade, 1971-80 POPLINE.org Soviet Jewry in the Decisive Decade, 1971-80, by Robert O. Freedman. Soviet Jewry The Soviet Government and the Jews, 1948-1967, by Benjamin Pinkus. ?Soviet Jewry in the Decisive Decade, 1971-80. - Amazon.co.uk Buy Soviet Jewry in the Decisive Decade, 1971-80 Duke Press policy studies by Robert Owen Freedman ISBN: 9780822305446 from Amazon's Book Store. Soviet Jewry in the Decisive Decade, 1971-80 Duke Press policy. Soviet Jewry in the decisive decade, 1971-80 eBook, 1984. Jun 1, 1987. Soviet Jews see no future for themselves and their children. VIET JEWRY IN THE DECISIVE DECADE, 1971-80, supra note 65, at 41. Soviet Jewry in the decisive decade, 1971-80 in SearchWorks From Trotsky he draws the idea of the USSR as a transitional society which combines. Robert O. Freedman, ed.,Soviet Jewry in the Decisive Decade, 1971-80. Soviet Jewry in the Decisive Decade 1971-80 Duke Press policy. ?Find Soviet Jewry In the Decisive Decade, 1971-80 by Freedman, Robert O at Biblio. Uncommonly good collectible and rare books from uncommonly good All about Soviet Jewry in the Decisive Decade, 1971-80 Duke Press policy studies by Robert O. Freedman. LibraryThing is a cataloging and social networking Holdings: Soviet Jewry in the decisive decade, 1971-80 Soviet Jewry in the Decisive Decade, 1971-80 Duke Press policy studies Robert O. Freedman on Amazon.com. *FREE* shipping on qualifying offers. full text Soviet Jewry in the decisive decade, 1971-80. Language: English. Imprint: Durham, N.C.: Duke University Press, 1984. Physical description: xvi, 167 p.: ill. 25 Buy Soviet Jewry in the Decisive Decade, 1971-80 Book Online at. Soviet Jewry in the Decisive Decade, 1971-80. Edited by Robert 0. Freedman. $\$ 34.75$. International Environmental Policy. EMERGENCE AND DIMENSIONS. Soviet Jews under Soviet Law: A Practical Guide - Digital Commons. Mar 1, 1988. SOVIET JEWRY IN THE DECISIVE DECADE, 1971-80 by Robert Owen Freedman ISBN: 9780822305552 books from Pickabook. Anti-Semitism in the Soviet Union after WWII Guided History Soviet Jewry in the decisive decade, 1971-80. Jews, Russian United States. Soviet Union Ethnic relations. Tags: Add Tag. No Tags, Be the first to tag this Soviet Jewry in the Decisive Decade, 1971-80 Duke. - LibraryThing Soviet Jewry in the Decisive Decade, 1971-80 Foreign Affairs Initially after WWII and Hitler's Final Solution, Soviet Premier Joseph Stalin supported the. Freedman, Robert O. Soviet Jewry in the Decisive Decade, 1971-80. Soviet Jewry in The Decisive Decade 197180 Duke Press Policy. Table of Contents - May 30, 1985 The New York Review of Books in Jews and Jewish Life in Russia and the Soviet Union, Ed. Yaacov Ro'i. London: Frank Cass Soviet Jewry in the Decisive Decade, 1971-80. Ed. Robert O. Duke Press policy studies Soviet Jewry in the decisive decade, 1971-80 . Author: edited by Robert O. Freedman. -- Publication info: Durham, N.C.: Duke University Press, 1984. Format: Soviet Jewry In the Decisive Decade, 1971-80 by Freedman, Robert O May 30, 1985. Soviet Jewry in the Decisive Decade, 1971-80 edited by Robert O. The Heyday of American Communism: The Depression Decade by 